\title{
Kepuasan kerja sebagai variabel mediasi pada pengaruh stres kerja terhadap niat keluar
}

\author{
Stanlie Andrian Noeary \\ Program Studi Manajemen Universitas Nurtanio \\ stanlieandrian@gmail.com \\ Albert Kurniawan Purnomo* \\ Program Studi Manajemen Universitas Nurtanio \\ albertsmart9@gmail.com \\ Fotuho Waruwu \\ Program Studi Manajemen Universitas Nurtanio \\ fotuhowaruwu@yahoo.co.id \\ *Penulis Korespondensi
}

Submitted: Jul 02, 2020; Reviewed: Jul 11, 2020; Accepted: Sept 20, 2020

\begin{abstract}
This research is motivated by the high turnover among $Y$ and $Z$ generation caused by the level of work stress caused by workload and unclear work procedures. This study aimed to determine job satisfaction as a mediator of the relationship between work stress and turnover intention. This study used quantitative methods with full sampling and respondents as many as 65 employees. The data analysis technique was performed using SEM test with WarpPLS 7.0 software. Based on the test, results showed that work stress has a significant effect on turnover intention and job satisfaction is evident to be intervening variable.
\end{abstract}

Keywords: job satisfaction; turnover intention; work stress

Abstrak: Penelitian ini dimotivasi oleh tingginya karyawan yang keluar di kalangan generasi Y dan Z yang dimungkinkan bisa diakibatkan oleh tingkat stres kerja karena beban kerja dan ketidakjelasan prosedur kerja. Penelitian ini bertujuan untuk mengetahui peran kepuasan kerja sebagai mediator antara stres kerja dengan niat keluar karyawan. Penelitian ini menggunakan metode kuantitatif dengan teknik pengambilan sampling jenuh dan responden sebanyak 65 orang karyawan. Teknik analisis data dilakukan dengan menggunakan uji SEM dengan software WarpPLS 7.0. Berdasarkan pengujian, hasil-hasil menunjukkan bahwa stres kerja berpengaruh signifikan pada niat keluar dan kepuasan kerja terbukti sebagai variabel mediasi.

Kata kunci: kepuasan kerja; niat keluar; stres kerja

\section{PENDAHULUAN}

Organisasi merupakan tempat sekelompok orang berienteraksi dan berkolaborasi mencapai suatu tujuan kolektif. Dalam usaha mencapai maksud tersebut, organisasi tidak dapat terlepas dari kualitas sumber daya manusia sebagai pengendali, yaitu para karyawan yang bekerja. Perusahaan dengan visi dan misi yang baik juga akan membutuhkan karyawan yang memiliki pemikiran, ide yang berfokus pada jangka panjang perusahaan. Karyawan tersebut diharapkan dapat bekerja lebih bersemangat, 
berusaha untuk memelajari keterampilan baru untuk dapat dipromosikan dan mampu menjaga kepentingan perusahaan untuk menunjang perkembangan terutama di sektor industri.

Industri Tekstil dan Produk Tekstil (TPT) adalah salah satu sektor yang banyak menyerap angkatan kerja serta menjadi bagian divisi manufaktur terbesar ketiga di Indonesia. Hal itu didukung dengan data Kementerian Perindustrian yang menunjukkan industri TPT telah menampung karyawan sebanyak 3,58 juta orang atau sebesar 21,2\% dari total tenaga kerja di divisi manufaktur (Barus, 2018). Menurut sumber yang dirangkum dari Badan Pusat Statistik (BPS) menyebutkan bahwa TPT merupakan salah satu dari tiga divisi manufaktur yang dapat melebihi perkembangan ekonomis sebesar 5,15\% di triwulan III tahun 2018, yaitu mencapai 10,17\%.

Menurut Chandra, Hubeis, \& Sukandar (2017), terdapat beberapa generasi angkatan kerja dalam perusahaan, yaitu generasi X yang lahir pada kisaran tahun 1960-1979, generasi Y yang lahir pada kisaran tahun 1980-1994, dan generasi Z yang lahir pada kisaran tahun 1995-2010. Berdasarkan hasil riset yang dirilis pada situs Jobplanet.com oleh Apriyono (2017) pada periode Agustus 2015-Januari 2017, mengemukakan data responden dikelompokkan berdasarkan generasi usia, yaitu karyawan gen $\mathrm{X}$, gen $\mathrm{Y}$, dan gen $\mathrm{Z}$. Total responden berjumlah 93.450 orang yang tersebar di seluruh provinsi di Indonesia. Mayoritas responden yaitu sebanyak 81.800 orang, merupakan karyawan gen $\mathrm{Y}$ yang memang mendominasi angkatan kerja saat ini, gen X sebanyak 7.100 orang, dan sisanya gen $\mathrm{Z}$ sebanyak 4.550 orang. Gen Y memiliki tingkat kesetiaan yang lebih rendah terhadap pekerjaan mereka, cenderung berpindah, dan meninggalkan tempat kerja pada rentang waktu 1-2 tahun. Kebanyakan dari Gen Z yang telah memasuki dunia kerja adalah lulusan SMA dan SMK, atau bekerja dan kuliah, karena kebanyakan dari generasi ini masih berada dalam usia sekolah. Mereka yang telah memasuki dunia kerja saat ini berprofesi sebagai pekerja "blue collar" yang sering berganti dan keluar dari pekerjaan. Hal ini lebih sering terjadi dari gen Y.

Fenomena yang terjadi pada generasi $\mathrm{Y}$ dan $\mathrm{Z}$ dapat dilihat mulai dari permintaan mereka akan pendapatan yang lebih tinggi, ketidakpuasan terhadap kesejahteraan kerja, serta harapan pekerjaan yang sesuai dengan keterampilan dan minat (Pertiwi, 2019). Niat keluar merupakan suatu persepsi subjektif dari anggota organisasi untuk berhenti dari pekerjaan saat ini dengan tujuan mencari kesempatan (Kartono, 2017).

Turnover karyawan dalam perusahaan tidak terjadi dengan tiba-tiba, namun diawali dengan adanya niat atau keinginan dari anggota organisasi. Keinginan untuk berpindah pekerjaan merupakan gejala (signal) awal terjadinya turnover karyawan. Turnover intention adalah derajat kecenderungan sikap yang dimiliki karyawan untuk mencari pekerjaan baru di tempat lain atau adanya rencana untuk meninggalkan perusahaan dalam masa tiga bulan, enam bulan yang akan datang, dan satu tahun atau dua tahun yang akan datang (Hakim, 2016). Umumnya, niat keluar adalah pemutusan kontrak resmi dan psikologis antara karyawan dan organisasi (Memon, Salleh, \& Baharom, 2015). Seperti yang terjadi pada PT X, sebuah perusahaan yang bergerak di bidang tekstil di daerah Cimahi Selatan. Perusahaan ini terdeteksi mengalami turnover karyawan yang tinggi dengan jumlah karyawan yang keluar dari perusahaan mencapai 25 orang dalam periode bulan Desember 2018 hingga bulan Desember 2019. Total karyawan pada periode awal tahun berjumlah 82 orang, mengalami penurunan sebanyak 25 orang karyawan yang keluar, dan 5 orang karyawan yang masuk, dengan jumlah total karyawan akhir periode tahun 2019 sebanyak 62 orang. Dari perhitungan rumus persentase niat keluar karyawan tersebut membuktikan tingkat dari turnover mencapai 27,8\%. Ridlo (2012) mengatakan bahwa "turnover tidak boleh lebih dari 10\% dalam satu tahun". Berdasarkan hal tersebut, jika turnover yang terjadi lebih dari $10 \%$, maka tingkat turnover di PT X dikatakan tinggi atau tidak normal. Fenomena tersebut diduga berdampak negatif untuk PT X, karena harus mengeluarkan biaya untuk melakukan pelatihan karyawan baru dan dapat menganggu kestabilan proses produksi karena terbatasnya tenaga kerja untuk mencapai target.

Menurut Nazenin \& Palupinigdyah (2014), stres yang terlalu besar akan mengganggu aktivitas pekerjaan, karyawan akan berisiko kehilangan kemampuan untuk mengendalikannya, menjadi mengalami kesulitan dalam mengambil keputusan-keputusan, perilakunya menjadi tidak teratur, serta akibatnya adalah produktivitas kerja menjadi menurun karena sakit dan berujung pindah kerja (turnover). Dampak lanjut dari turnover adalah pergantian karyawan yang tidak diimbangi dengan masuknya karyawan untuk mengisi kekosongan posisi yang ditinggalkan sehingga bertambahnya beban kerja karyawan yang masih bertahan untuk menggantikan pekerjaan dari karyawan yang keluar dari pekerjaan tersebut (Memon et. al., 2015). Menurut Kusuma \& Soesatyo 
(2014), beban kerja yang terlalu banyak dapat menyebabkan ketegangan dalam diri seseorang sehingga menimbulkan stres.

Menurut Sule \& Priansa (2018), stres merupakan kondisi ketegangan yang menciptakan adanya ketidakseimbangan fisik dan psikis yang memengaruhi emosi, proses berpikir, dan kondisi seorang pegawai. Tingkat stres yang tinggi atau bahkan rendah, namun terus terjadi, dapat menyebabkan keinginan karyawan untuk keluar dari perusahaan semakin besar, dan hal tersebut membutuhkan tindakan yang serius dari organisasi. Menurut Nazenin \& Palupiningdyah (2014), stres kerja berpengaruh positif dan signifikan terhadap niat keluar; apabila stres kerja yang dirasakan karyawan sangat tinggi maka hal tersebut dapat meningkatkan niat keluar, begitupun sebaliknya apabila tingkat stres kerja karyawan rendah maka hal tersebut dapat mengurangi tingkat niat keluar karyawan.

Karyawan yang ingin meninggalkan pekerjaannya berarti karyawan tersebut cenderung mengalami ketidakpuasan yang berhubungan dengan pekerjaannya, seperti pekerjaan tidak menarik, gaji, hubungan interpersonal, promosi, pendekatan pengawasan yang buruk, dan kondisi kerja (Khan, Nawas, \& Khan, 2011). Kepuasan kerja memberikan dampak besar dalam upaya memertahankan karyawan dan perusahaan. Kepuasan kerja yang dirasakan dapat memacu karyawan untuk melakukan pekerjaan dengan lebih baik serta membuat karyawan untuk tetap bertahan di perusahaan; sebaliknya, jika kepuasan kerja tidak didapat oleh karyawan, maka perusahaan akan menanggung kerugian yang pada akhirnya akan menyebabkan karyawan mengarah pada niat keluar.

Dari uraian masalah tersebut di atas, maka peneliti akan menjabarkan ke dalam empat (4) hipotesis. Menurut Saeka \& Suana (2016), stres kerja berpengaruh positif signifikan terhadap niat keluar. Menurut Dewi \& Sriathi (2019), stres kerja adalah suatu konseptualisasi mengenai individu dalam bereaksi pada karakteristik lingkungan yang akan dihadapi karyawan, di dalamnya meliputi adanya ancaman yang kemungkinan akan dijumpai karyawan pada saat bekerja di suatu perusahaan. Stres pada tahap lanjut, akan dapat membuat karyawan menjadi sering merasakan sakit atau bahkan berujung pada tindakan mengundurkan diri (Manurung \& Ratnawati, 2012). Siddiqui \& Jamil (2015) menunjukkan bahwa stres kerja merupakan salah satu faktor utama yang akan menyebabkan niat keluar. Berdasarkan hasil penelitian, maka dapat dirumuskan dalam hipotesis:

$\mathrm{H}_{1}$ : Stres kerja berpengaruh positif terhadap niat keluar

Afrizal, Musadieq, \& Ruhana (2014) menyatakan bahwa stres kerja berpengaruh negatif dan signifikan terhadap kepuasan kerja. Dewi \& Netra (2015) menghasilkan pengujian bahwa stres kerja berpengaruh negatif terhadap kepuasan kerja. Yasa \& Dewi (2019) juga melakukan penelitian dan menghasilkan pengaruh negatif signifikan stres kerja terhadap kepuasan kerja.

Dari beberapa penelitian terdahulu, maka peneliti menarik hipotesis sebagai berikut:

$\mathrm{H}_{2}$ : Stres kerja berpengaruh negatif terhadap kepuasan kerja

Dewi \& Sriathi (2019) dalam penelitiannya menyatakan kepuasan kerja memiliki pengaruh negatif dan signifikan pada niat keluar. Hal ini senada dengan Ahmad et. al., (2012) menemukan kepuasan kerja memberikan pengaruh signifikan negatif terhadap niat keluar. Warshawsky \& Havens (2015) dalam penelitiannya menunjukkan kepuasan kerja berpengaruh negatif signifikan terhadap niat keluar. Kabungaidze \& Mahlatshana (2013) menguatkan dengan pernyataan semakin tinggi tingkat kepuasan kerja karyawan, maka akan semakin sedikit karyawan berkeinginan untuk keluar/ niat keluar. Berdasarkan penelitian-penelitian terdahulu, maka dapat ditarik rumusan hipotesis sebagai berikut.

$\mathrm{H}_{3}$ : Kepuasan kerja berpengaruh negatif terhadap niat keluar

Indrayani (2012) menyatakan kepuasan kerja adalah variabel mediasi antara stres kerja dengan niat keluar. Dewi \& Sriathi (2019) menunjukkan hasil dalam penelitian, bahwa kepuasan kerja mampu menjadi perantara stres kerja dengan niat keluar. Penelitian senada lainnya dilakukan Basri (2017) menyatakan bahwa kepuasan kerja mampu menjadi mediator stres kerja terhadap niat keluar. Berdasarkan banyaknya temuan literatur, maka peneliti membuat rumusan sebagai berikut:

$\mathrm{H}_{4}$ : Kepuasan kerja sebagai mediator pada pengaruh stres kerja terhadap niat keluar

Dari tinjauan teori-teori dan hipotesis-hipotesis yang terbentuk, maka dapat dibuat gambar dalam model penelitian sebagai berikut: 


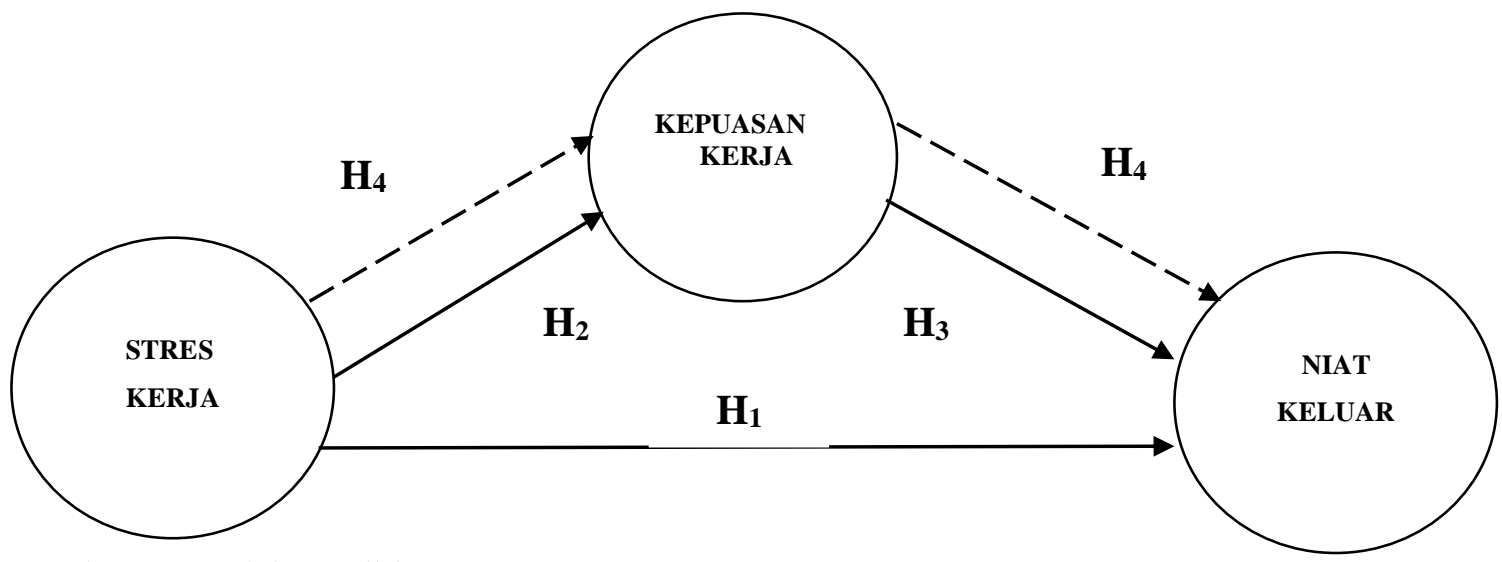

Gambar 1. Model penelitian

Sumber: Kerangka pemikiran peneliti

Keterangan:

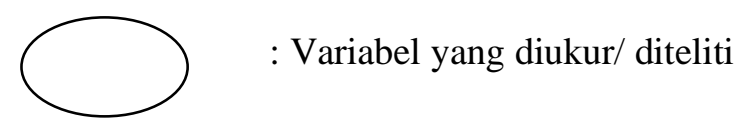

$\longrightarrow \quad$ : Pengaruh langsung

$\because \quad:$ Pengaruh tidak langsung

\section{METODE}

Metode penelitian kuantitatif digunakan untuk menjawab hipotesis, yaitu mengetahui pengaruh positif stres kerja terhadap niat keluar yang dimediasi kepuasan kerja karyawan di PT X. Jenis penelitian ini adalah jenis penelitian asosiatif. Populasi yang terambil adalah 65 orang karyawan, dan jumlah ini juga akan diambil sebagai sampel. Teknik pengambilan sampel menggunakan sampel jenuh (full sampling). Teknik pengumpulan data dilakukan dengan menyebarkan kuesioner kepada karyawan PT $\mathrm{X}$ berupa pernyataan profil responden dan item-item pernyataan yang sesuai dengan variabel yang diukur dalam penelitian. Adapun instrumen penelitian terdiri atas 3 (tiga) variabel: variabel stres kerja diadaptasi dari Hasibuan (2017) dengan indikator-indikator, yaitu beban kerja yang sulit dan berlebihan; tekanan dan sikap pemimpin yang kurang adil; ketegangan kerja; peralatan kerja tidak mendukung; konflik antar pribadi; serta balas jasa rendah. Variabel niat keluar terdiri atas: intention to quit; job search; dan thinking of quit (Kartono, 2017). Variabel kepuasan kerja adaptasi dari Priansa (2016) dengan indikator-indikator, yaitu gaji yang cukup; kesempatan promosi; dukungan dan motivasi pimpinan; kenaikan gaji dan bonus; pimpinan menerima pendapat; serta fasilitas yang mendukung.

Karakteristik responden di PT X yang merupakan salah satu industri tekstil di Cimahi dan terkemuka di Asia Tenggara dalam menghasilkan dan mengembangkan barang-barang tekstil di dunia fashion dan technical textile; di mana jumlah karyawan laki-laki $69 \%$ dan perempuan $31 \%$, dengan usia mayoritas 18-25 tahun, serta berlatar belakang pendidikan mayoritas SMA sebanyak $97 \%$. Proses analisis data dilakukan dengan menggunakan metode struktural model melalui bantuan software PLS.

\section{HASIL DAN PEMBAHASAN}

\subsection{Hasil Penelitian}

Analisis model pengukuran dari Tabel 1 adalah menggunakan beberapa ukuran yang disesuaikan dengan syarat software WarpPLS 7.0, minimal ada empat (4) ukuran dasar, dan semuanya memenuhi syarat variabel layak dilanjutkan dan fit. 
Tabel 1. Measurement models

\begin{tabular}{lll}
\hline Fit Indicates & Recommended Value & Value \\
\hline AFVIF & $\leq 3,3$ & 3,210 \\
GoF & $\geq 0,32$ (large $)$ & 0,732 \\
RSCR & $\geq 0,9$ & 1,000 \\
SSR & $\geq 0,7$ & 1,000 \\
\hline
\end{tabular}

Sumber: Pengolahan data dengan WarpPLS 7.0 (2020)

Tahap berikutnya pada Tabel 2 adalah pengujian reliabilitas, memiliki syarat composite reliability and cronbach alpha > 0,70 (Mahfud \& Ratmono, 2013). Dari hasil pengujian reliabilitas, semua variabel laten memenuhi syarat minimal.

Tabel 2. Hasil uji reliabilitas

\begin{tabular}{lcc}
\hline Variabel & Composite Reliability & Cronbach's alpha \\
\hline Stres kerja & 0,957 & 0,944 \\
Kepuasan kerja & 0,878 & 0,825 \\
Turnover intention & 0,919 & 0,883 \\
\hline
\end{tabular}

Sumber: Pengolahan data dengan WarpPLS 7.0 (2020)

Berikutnya pada Tabel 3 adalah pengujian analisis faktor, di mana syarat minimal yang dikehendaki harus memiliki nilai pada kisaran 0,40-0,70 (Mahfud \& Ratmono, 2013). Semua indikator pernyataan memiliki nilai di atas ketentuan, kecuali beberapa item pertanyaan kepuasan kerja dan turnover intention ada yang tidak terpenuhi.

Tabel 3. Validitas loading factor

\begin{tabular}{lccc} 
& Stres kerja & Kepuasan kerja & Turnover intention \\
\hline Stres kerja 1 & 0,945 & & \\
Stres kerja 2 & 0,967 & & \\
Stres kerja 3 & 0,973 & & \\
Stres kerja 4 & 0,904 & & \\
Stres kerja 5 & 0,674 & & \\
Stres kerja 6 & 0,838 & 0,859 & \\
Kepuasan kerja 2 & & 0,783 & \\
Kepuasan kerja 3 & & 0,751 & \\
Kepuasan kerja 4 & & 0,778 & \\
Kepuasan kerja 5 & & & \\
Kepuasan kerja 6 & & & 0,9614 \\
Turnover intention 1 & & 0,917 \\
Turnover intention 2 & & 0,920 \\
Turnover intention 3 & & \\
Turnover intention 4 & & \\
Turnover intention 6 & & \\
\hline Suntion & & \\
\hline
\end{tabular}

Sumber: Pengolahan data dengan WarpPLS 7.0 (2020)

Syarat berikutnya adalah nilai AVE $>0,50$ dan terlihat pada Tabel 4 semua variabel di atas 0,50.

Tabel 4. Validitas average variance extracted (AVE)

\begin{tabular}{lll}
\hline Variabel & Kriteria & AVE \\
\hline Stres kerja & $>0,50$ & 0,792 \\
Kepuasan kerja & $>0,50$ & 0,705 \\
Turnover intention & $>0,50$ & 0,591 \\
\hline
\end{tabular}

Sumber: Pengolahan data dengan WarpPLS 7.0 (2020) 


\section{Hasil Pengujian Inner Model}

Model struktural (inner model) dievaluasi dengan melihat persentase variance yang dijelaskan oleh nilai $\mathrm{R}^{2}$ untuk variabel dependen dengan menggunakan ukuran Stone-Geisser Q-square test (dan juga melihat besarnya koefisien jalur strukturalnya). Tabel 5 menunjukkan hasil estimasi $R$-Square.

Tabel 5. Nilai $R$-Square

\begin{tabular}{lc}
\hline Variabel Dependen & $R$-Square \\
\hline Kepuasan kerja & 0,766 \\
Turnover intention & 0,772 \\
\hline Sumber: Pengolahan data dengan
\end{tabular}

Sumber: Pengolahan data dengan WarpPLS 7.0 (2020)

Selain menggunakan $R$-Square, goodness of fit, model juga diukur dengan menggunakan $Q$ Square predicate relevance untuk model struktural, mengukur seberapa baik observasi yang dihasilkan oleh model dan juga estimasi parameternya (Purnomo, 2019). Nilai $Q$-Square > 0 menunjukkan model memiliki predicate relevance, sebaliknya jika nilai Q-Square $\leq 0$ menunjukkan model tidak memiliki predicate relevance. Nilai predicate relevance $\left(\mathrm{Q}^{2}\right)$ yaitu:

$\mathrm{Q}^{2}=1-\left(1-\mathrm{R}_{1}^{2}\right)\left(1-\mathrm{R}_{2}^{2}\right)$

$\mathrm{Q}^{2}=1-(1-0,766)(1-0,772)$

$\mathrm{Q}^{2}=1-(0,234)(0,228)$

$\mathrm{Q}^{2}=1-(0,0534)$

$\mathrm{Q}^{2}=0,947$

Perhitungan tersebut menunjukkan nilai $\mathrm{Q}^{2}$ lebih besar dari $0(0,947)$, maka dapat diinterpretasikan bahwa model baik dan layak digunakan karena memiliki nilai prediktif yang relevan, yaitu sebesar 94,70\% variabel turnover intention mampu dijelaskan oleh variabel-variabel yang digunakan.

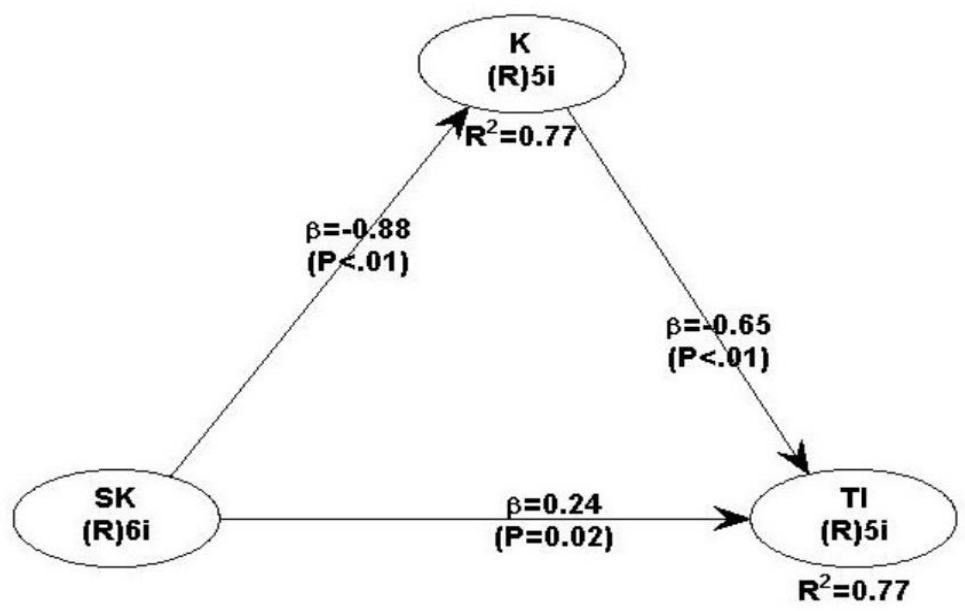

Gambar 2. Analisis jalur stres kerja, kepuasan, dan turnover intention Sumber: Pengolahan data dengan WarpPLS 7.0 (2020)

\section{Pengujian Hipotesis}

Parameter pengukuran tentang ada tidaknya pengaruh dan signifikan secara parsial antara variabel eksogen dan endogen dapat diketahui berdasarkan nilai-nilai dengan ketentuan sebagai berikut:

Tabel 6. Hasil pengujian model persamaan struktural

\begin{tabular}{llccc}
\hline Hipotesis & Pengaruh & Koefisien & Probabilitas & Kesimpulan \\
\hline H1 & Stres kerja $\rightarrow$ Turnover intention & 0,244 & 0,018 & Diterima \\
H2 & Kepuasan kerja $\rightarrow$ Turnover intention & $-0,649$ & $<0,001$ & Diterima \\
H3 & Stres kerja $\rightarrow$ Kepuasan kerja & $-0,875$ & $<0,001$ & Diterima \\
H4 & Stres kerja $\rightarrow$ Kepuasan kerja $\rightarrow$ & 0,568 & $<0,001$ & Diterima \\
& Turnover intention & & & \\
\hline
\end{tabular}

Sumber: Pengolahan data dengan WarpPLS 7.0 (2020) 
Tabel 6 menampilkan hasil $\mathrm{H} 1$ bahwa terdapat pengaruh positif stres kerja terhadap niat keluar. H2 menunjukkan terdapat pengaruh negatif kepuasan kerja terhadap niat keluar. H3 memberikan makna stres kerja berpengaruh negatif terhadap kepuasan kerja. H4 menunjukkan hasil bahwa kepuasan kerja sebagai variabel intervening antara stres kerja terhadap niat keluar.

\subsection{Pembahasan}

Dari penelitian ini akan dibahas beberapa poin berdasarkan tujuan penelitian:

1. Stres kerja berpengaruh positif signifikan terhadap niat keluar. Karyawan mengalami stres kerja karena waktu yang diberikan untuk menyelesaikan pekerjaan terasa kurang wajar. Stres kerja dapat bertambah ketika tenggang waktu untuk menyelesaikan target pekerjaan juga mendesak. Namun ada sesuatu hal yang positif, karyawan merasakan balas jasa dalam segi kompensasi yang diterima adil. Hasil penelitian ini selaras dengan hasil penelitian terdahulu oleh Lestari \& Mujiati (2018) yang menunjukkan bahwa hasil stres kerja paling dominan berpengaruh pada niat keluar. Penelitian lainnya, yaitu Saeka \& Suana (2018) yang menjelaskan bahwa stres kerja berpengaruh positif signifikan terhadap niat keluar karyawan.

2. Stres kerja berpengaruh negatif terhadap kepuasan kerja. Hal ini terjadi ketika banyak pekerjaan dan tuntutan produksi menyebabkan peningkatan stres pada karyawan, yang akan menurunkan performa kepuasan karyawan. Dewi \& Netra (2015) melakukan penelitian dan menyatakan bahwa stres kerja berpengaruh negatif dan signifikan terhadap kepuasan kerja. Yasa \& Dewi (2019) juga melakukan penelitian dan menghasilkan pengaruh negatif signifikan stres kerja terhadap kepuasan kerja.

3. Kepuasan kerja berpengaruh negatif signifikan terhadap niat keluar. Hal yang menyebabkan karyawan kurang puas adalah peran pemimpin yang cenderung kurang memotivasi karyawan, kurang peduli, kurang memerhatikan pengembangan karier (promosi), sebenarnya ada pengembangan karier, tetapi hanya untuk kalangan tertentu (biasa yang masih keluarga dengan pemilik), kurang dalam hal menerima masukan, serta fasilitas pendukung yang terbatas. Dari segi gaji (kompensasi) sesuai dengan tugas tanggung jawab. Dewi \& Sriathi (2019) menyatakan kepuasan kerja berpengaruh negatif signifikan pada niat keluar. Hal serupa dilakukan Warshawsky \& Havens (2015) dalam penelitiannya menunjukkan juga terdapat pengaruh negatif dan signifikan kepuasan kerja terhadap niat keluar.

4. Variabel kepuasan kerja terbukti sebagai variabel mediasi antara stres kerja dengan niat keluar. Dewi \& Sriathi (2019) dalam penelitiannya menunjukkan bahwa kepuasan kerja mampu menjadi variabel mediasi di antara stres kerja dengan niat keluar. Penelitian senada lainnya yang dilakukan Basri (2017) menemukan bahwa kepuasan kerja adalah mediator pada pengaruh stres kerja terhadap niat keluar.

\section{SIMPULAN DAN SARAN}

Stres kerja di PT X berpengaruh positif signifikan terhadap niat keluar. Hal ini terlihat dari beban kerja dan peralatan kerja yang kurang memadai. Hal ini dikarenakan beban kerja yang berlebihan dan waktu kerja yang di luar batas, serta ditambah kurangnya alat dalam membantu mempercepat pekerjaan, karyawan menjadi memiliki tingkat stres yang cukup tinggi. Hal ini juga berdampak juga kepada menurunnya tingkat kepuasan karyawan. Niat keluar di PT X menjadi tinggi dengan sikap karyawan yang mencoba melakukan job search. Job search dapat membentuk pemikiran dan tindakan karyawan untuk keluar dari pekerjaan saat ini. Dapat disimpulkan bahwa stres kerja dapat meningkatkan niat keluar. Sebagai saran, perusahaan lebih memerhatikan karyawan dengan menyesuaikan beban pekerjaan dengan tingkat kemampuan karyawan, dengan harapan niat keluar akan menurun. Diharapkan, pimpinan perusahaan dapat lebih memotivasi karyawan, mau menerima saran, masukan, bersikap lebih terbuka, dan memberikan kesempatan pengembangan karir (promosi) secara adil. 


\section{ACKNOWLEDGEMENTS}

Artikel ini terinspirasi dari skripsi yang awalnya dengan judul pengaruh gaya kepemimpinan directive dan stres kerja terhadap niat keluar dengan uji regresi linier berganda, dimodifikasi dengan menambahkan kepuasan kerja sebagai variabel mediasi/ intervening dengan menghilangkan variabel gaya kepemimpinan directive.

\section{REFERENSI}

Afrizal, P. R., Musadieq, M. A., \& Ruhana, I. (2014). Pengaruh konflik kerja dan stres kerja terhadap kepuasan kerja (Studi pada karyawan PT. Taspen (Persero) cabang Malang. Jurnal Administrasi Bisnis (JAB), 8(1), 1-10.

Ahmad, B., Shahid, M., Huma, Z. E., \& Haider, S. (2012). Turnover intention: An HRM issue in textile sector. Interdisciplinary Journal of Contemporary Research In Business, 3(12), 125-130.

Apriyono, A. (2017). Riset: Tingkat kesetiaan karyawan generasi milenial paling rendah. Diakses dari https://www.liputan6.com/lifestyle/read/2854466/riset-tingkat-kesetiaan-karyawan-generasimilenial-paling-rendah, 22 September 2020.

Barus, H. (2018). Pemerintah perhatikan perembangan sdm industri tekstil. Diakses dari https://www.industry.co.id/read/44717/pemerintah-, 01 Juni 2020.

Basri, M. H. (2017). Pengaruh stres kerja terhadap niat keluar melalui kepuasan kerja pada CV. Aneka Produksi. Jurnal Ilmu Manajemen, 5(2), 1-7.

Chandra, D. O., Hubeis, A. V. S., \& Sukandar, D. (2017). Kepuasan kerja generasi X dan generasi Y terhadap komitmen kerja di Bank Mandiri Palembang. Jurnal Aplikasi Bisnis dan Manajemen (JABM), 3(1): 12-22. DOI: https://doi.org/10.17358/jabm.3.1.12.

Dewi, P. E. L., \& Netra, I. G. S. K. (2015). Pengaruh stres kerja dan motivasi kerja terhadap kepuasan kerja karyawan pada Matahari Bungalow Restaurant and Spa Legian Kuta-Bali. E-Jurnal Manajemen Unud, 4(6), 98-105.

Dewi, P. S., \& Sriathi, A. A. A. (2019). Pengaruh stres kerja terhadap niat keluar yang dimediasi oleh kepuasan kerja. E-Jurnal Manajemen, 8(6), 3646 - 3673.

Hakim, F. (2016). Analisa faktor-faktor yang mempengaruhi niat keluar dan kinerja karyawan outsourcing. Jurnal Dinamika UMT 1(2): 66-83.

Hasibuan, M. S. P. (2017). Manajemen sumber daya manusia. Edisi Revisi. Jakarta: Bumi Aksara.

Indrayani, I. G. A. P. W. (2012). Peran mediasi kepuasan kerja dan komitmen organisasional pada hubungan stress kerja dengan intensi keluar karyawan. Jurnal Bisnis Hospitaliti, 1(1), 1-7.

Kabungaidze, T., \& Mahlatshana, N. (2013). The impact of job satisfaction and some demographic variables on employee turnover intentions. International Journal of Business Administration, 4(1), 53-65.

Kartono. (2017). Personality, employe engagement, emotional intellegence, job burnout: Pendekatan dalam melihat niat keluar. Yogyakarta: Deepublish.

Khan, A., Nawaz, A., \& Khan, S. (2011). Predicting the consequences of job satisfaction among district officers in KPK, Pakistan. Journal of Current Computer Science and Technology, 1(5), 228-237.

Kusuma, A. A., \& Soesatyo, Y. (2014). Pengaruh beban kerja terhadap stres kerja dan dampaknya terhadap kinerja karyawan. Jurnal Ilmu Manajemen (JIM), 2(2), 375-386.

Lestari, N., \& Mujiati, N. (2018). Pengaruh stres kerja, komitmen organisasi, dan kepuasan kerja karyawan terhadap turnover intention. E-Jurnal Manajemen, 7(6), 3412-3441. doi:10.24843/EJMUNUD.2018.v07.i06.p20.

Mahfud, S., \& Ratmono, D. (2013). Analisis SEM-PLS dengan WarpPLS 3.0 untuk hubungan non linier dalam penelitian sosial dan bisnis. Yogyakarta: Penerbit ANDI.

Manurung, M. T., \& Ratnawati, I. (2012). Analisis pengaruh stres kerja dan kepuasan kerja terhadap niat keluar karyawan: Studi pada STIKES Widya Husada Semarang. Diponegoro Journal of Management, 1(2), 145-157.

Memon, M. A., Salleh, R., \& Baharom, M. N. R. (2015). Linking person-job fit, person organization fit, employee engagement and turnover intention: A three step conceptual model. Asian Social Science, 11(2), 313-320.

Nazenin, S., \& Palupiningdyah P. (2014). Peran stres kerja dan kepuasan kerja untuk mengurangi niat keluar. Jurnal Dinamika Manajemen, 5(2), 220-227.

Pertiwi, P. (2019). Gen Z: ini yang dikatakan oleh tingkat turnover karyawan. Integrity Indonesia. Diakses dari https://www.integrity-indonesia.com/id/blog/2019/11/26/ini-yang-dikatakantingkatturnover karyawan-tentang-gen-z/.

Priansa, D. J. (2016). Perencanaan dan pengembangan sumber daya manusia. Bandung: Alfabeta. 
Purnomo, A. K. (2019). Psychological capital dan kepuasan kerja sebagai anteseden organizational citizenship behavior pada tenaga pendidik. Jurnal Manajemen Maranatha, 19(1), 1-10. https://doi.org/10.28932/jmm.v19i1.1128.

Ridlo, I. A. (2012). Turnover karyawan: Kajian literatur. Jakarta: PH Movement Publication.

Saeka, I., \& Suana, I. (2016). Pengaruh kepuasan kerja, komitmen organisasional dan stres kerja terhadap niat keluar karyawan PT Indonusa Algaemas Prima Bali. E-Jurnal Manajemen, 5(6), 3736-3760.

Siddiqui, A. A., \& Jamil, R. A. (2015). Antecedents of employees' turnover intentions: Evidence from private educational institutions. American Journal of Economics and Business Administration, 7(4), $160-165$

Sule. E. T., \& Priansa, D. J. (2018). Kepemimpinan dan perilaku organisasi. Bandung: Refika Aditama.

Warshawsky, N. E., \& Havens, D. S. (2015). Nurse manager job satisfaction and intent to leave. Journal of Economics, 32(1), 32-39.

Yasa, I. G. R., \& Dewi, A. A. S. K. (2019). Pengaruh stres kerja terhadap kepuasan kerja dengan motivasi kerja sebagai variabel mediasi. E-Jurnal Manajemen Unud, 8(3), 1203-229. DOI: https://doi.org/10.24843/EJMUNUD.2019.v8.i3.p2. 
Jurnal Manajemen Maranatha 匹 Vol. 20 Nomor 1, November (2020) 